https://doi.org/10.52058/2708-7530-2021-4(10)-61-72

Кузьменко Ганна Олександрівна аспірант кафедри публічного адміністрування, Міжрегіональна Академія управління персоналом, вул. Фрометівська, 2, м. Київ, 03039, тел.: (044) 490-95-00, e-mail: annakuzmenko96@ukr.net, https://orcid.org/0000-0003-0672-7633

\title{
СТАН ТА ПРОБЛЕМИ КАДРОВОГО ЗАБЕЗПЕЧЕННЯ В ДЕРЖАВНОМУ УПРАВЛІННІ
}

Анотація. У статті проаналізовано стан та проблеми кадрового забезпечення в державному управлінні. Розглянуто нормативно-правове забезпечення в кадровій системі; сутність складного і багатогранного процесу людських ресурсів, орієнтованої на формування, розвиток та раціональне використання персоналу в державному управлінні.

Підвищення рівня професійної культури державних службовців можливе за умови об'єктивного оцінювання, мотивації та справедливого заохочення праці цієї особливої соціально-професійної групи. Поряд з тим, розвинена професійна культура державних службовців дозволяє ефективно використати кадровий потенціал державної служби. Це, в свою чергу, прямо впливає на оцінку діяльності державних службовців громадянами. У вітчизняній науковій традиції державного управління приділяється велике значення «людському фактору» (особливостям особистості фахівця) у процесі формування професійної культури державних службовців, менша роль відводиться «організаційному фактору» об'єктивним принципам, умовам, нормам, що визначають зразки поведінки і діяльності. Наразі державні службовці повинні стати активними учасниками реформи децентралізації влади, здійснювати їі кадрове забезпечення, оновлювати державні структури людськими ресурсами, а також здійснювати їх підготовку до змін, що сприятиме мобільності кадрів, забезпеченню їх професійного вдосконалення.

Прийнятність змісту цінностей державної служби для державних службовців залежить від організаційної структури, контексту та соціально-політичного режиму iї функціонування, зокрема від характеру та можливостей реально працюючої системи зворотного зв'язку в системі державного управління. Саме в рамках формування системи зворотного зв'язку і застосовуються різні методи оцінювання етичних складових державного управління. Процес формування управлінської культури у програмах професійної підготовки державних 
службовців потребує суттєвого посилення їх індивідуальної спрямованості. Додаткових наукових пошуків потребує проблема безперервності процесу формування управлінської культури кадрів державної служби.

Ключові слова: кадрове забезпечення, кадрова політика, державне управління, антикорупційні механізми.

Kuzmenko Hanna Olexandrivna Postgraduated Student, Department of Public Administration, Interregional Academy of Personnel Management, Frometivska St., 2, Kyiv, 03039, tel.: (044) 490-95-00, e-mail: anna-kuzmenko96@ukr.net, https://orcid.org/0000-0003-0672-7633

\section{STATE AND PROBLEMS OF HUMAN RESOURCES IN PUBLIC ADMINISTRATION}

Abstract. The article analyzes the state and problems of staffing in public administration. The normative-legal provision in the personnel system is considered; the essence of a complex and multifaceted process of human resources, focused on the formation, development and rational use of personnel in public administration.

Improving the professional culture of civil servants is possible provided that the work of this special socio-professional group is objectively evaluated, motivated and fairly encouraged. At the same time, the developed professional culture of civil servants allows to use the personnel potential of the civil service effectively. This, in turn, directly affects the assessment of civil servants by citizens. In the domestic scientific tradition of public administration great importance is attached to the "human factor" (personality traits) in the formation of professional culture of civil servants, less role is given to the "organizational factor" - objective principles, conditions, norms that determine patterns of behavior and activity. At present, civil servants must become active participants in the reform of decentralization of power, provide its staffing, update state structures with human resources, as well as prepare them for change, which will promote the mobility of staff, ensuring their professional development.

The acceptability of the content of civil service values for civil servants depends on the organizational structure, context and socio-political regime of its operation, in particular on the nature and capabilities of a real feedback system in the public administration system. It is within the framework of the formation of the feedback system that various methods of assessing the ethical components of public administration are used. The process of forming a managerial culture in the training programs of civil servants requires a significant strengthening of their individual orientation. The problem of continuity of the process of formation of the managerial culture of civil service personnel requires additional scientific research. 
Keywords: personnel, personnel policy, public administration, anti-corruption mechanisms.

Постановка проблеми. Кадрове забезпечення в державному управлінні в Україні характеризується значним комплексом системних проблем, спричинених процесами трансформації в політиці, соціокультурній сфері та певними недоліками в кадровій роботі 3 формування та реалізації державної кадрової політики. Перш за все слід зазначити, що сьогодні в Україні не існує національної концепції та програм реконструкції, розвитку та використання людського потенціалу. Кадрова система країни та іï установ знаходиться в стані невизначеності, а нормативно-правове забезпечення державної кадрової системи залишається недосконалим.

На сучасному етапі розвитку української держави кадрове забезпечення державного управління відіграє ключову роль у вирішенні широкого кола поточних та майбутніх проблем розвитку суспільства в цілому. Його суть полягає в тому, що це насамперед складний і багатогранний процес людських ресурсів, орієнтований на формування, розвиток та раціональне використання персоналу в державному управлінні. По-друге, кадрове забезпечення державного управління оновлення трудових ресурсів, головний елемент управління людськими ресурсами, необхідний фактор досягнення цілей соціального розвитку. По-третє, це системний механізм, спрямований на оновлення кваліфікованих працівників органів державної влади. Кадровий потенціал відповідає поточним та очікуваним можливостям працевлаштування, які визначаються кількістю, віковою структурою, професією, кваліфікацією та іншими характеристиками державного персоналу, здатного досягти запланованих цілей [9]. Ефективне створення людських ресурсів у державних органах допоможе вирішити деякі завдання: визначення співвідношення між кількістю працівників з різною професійною кваліфікацією 3 метою досягнення максимальної узгодженості між робочими структурами, робочими місцями та персоналом; забезпечення оптимального рівня навантаження працівників на повну реалізацію їх особистого потенціалу та підвищення ефективності їх роботи; оптимізація структури працівників з різним функціональним змістом праці [1, с. 32].

Мета статті полягає у дослідженні стану кадрового забезпечення в державному управлінні та запропонованих шляхах вирішення проблематики.

Аналіз останніх досліджень і публікацій. У сучасних умовах вирішення кадрових питань є однією із найактуальніших проблем державного управління в Україні, визначальним аспектом формування та функціонування державної влади. Кадрова забезпечення виступає як важливий чинник політики держави. Проблеми формування та реалізації державного кадрового забезпечення в цілому 
та кадрових процесів і технологій, зокрема, міститься у роботах вітчизняних учених: В. Борденюка, О. Вольської, Л. Гогіної, Ю. Гогіної, О. Губи, С. Дембіцької, Я. Жовнірчика, О. Ковальової, Г. С. Куйбіди, А. Михненка, С. Серьогіна, В. Олуйка, Т. Пахомової, О. Оболенського та інших науковців.

Виклад основного матеріалу. У даний час в Україні існують певні етапи формування людських ресурсів органів державної влади: першим етапом кадрового забезпечення $є$ підготовка професійних управлінських кадрів, i для цього із системи їх професійної підготовки сформована мережа навчальних закладів: спеціалізовані навчальні заклади з різним статусом та ресурсами; центри з перепідготовки та підвищення кваліфікації працівників органів державної влади, місцевого самоврядування, державних підприємств, установ та організацій; галузеві навчальні заклади вищої та післядипломної освіти, які мають ліцензію на підвищення кваліфікації державних службовців; установи системи Міністерства освіти і науки України, які готують кваліфікованих державних службовців та службу в органах місцевого самоврядування, а також спеціалізовані навчальні заклади із запровадженням підготовки фахівців освітньо-кваліфікаційного рівня бакалавр та магістр за спеціальністю "Державне управління" в низка провідних вищих навчальних закладів України (4 рівні акредитації), приватні вищі навчальні заклади [13, с. 27]. Другий етап кадрового забезпечення - це підбір персоналу діяльність, спрямована на визначення того, чи можуть кандидати виконувати функціональні завдання на певній посаді. На жаль, процедури прийому до державних установ в Україні не враховують індивідуальні особливості кандидатів, а конкурси в основному є формальними. Також дуже часто вибір посади грунтується виключно на бажаннях керівника, без урахування специфіки корпоративної культури. Інша проблема - відсутність інформації про кандидата фактично розглядається у ключові моменти життя уряду, а також особливості професійних обов'язків кандидата, мотиваційна система. Таким чином, в даний час великий вплив на процес відбору державних органів здійснює монополізація цієї процедури керівництвом, що виявляється суб'єктивною оцінкою комерційних та моральних якостей працівників та випадками корупції при відборі [13, с. 45].

Третій етап включає організацію надання державних служб державним службовцям та працівникам органів місцевого самоврядування. Для надання якісної державної послуги органи державної влади повинні мати висококваліфікований та компетентний персонал. Для цього потрібна ефективна система державної роботи. Однак сучасні типи освіти не компенсують належним чином теоретичний рівень знань та навичок державних службовців та не забезпечують практичних навичок. Крім того, нинішній процес розробки програм професійного розвитку є незадовільним, і немає аналізу необхідних навичок. Професійні потреби, а тим більше лідерські навички, необхідні для керування 
потребами та змінами, пов'язаними з реформою державної служби, та успішного управління ними [1, с. 33].

Розробка та реалізація кадрової політики України у всіх сферах суспільної діяльності вимагає ефективної кадрової системи, яка складається 3 команди кадрових установ та організацій 3 відповідними ресурсами, які керують комплексним управлінням кадровими процесами, а також організаційних структур країни та відносин, для досягнення конкретних пріоритетів. Свропейські стандарти, їх ідеологія та програмне забезпечення. Це означає, насамперед, існування нормативно-правової бази та створення системи організацій, які керуватимуть процесами людських ресурсів у цих сферах [2].

В даний час в Україні не існує інтегрованої системи кадрів, яка б визначала:

- нерегульовані завдання та повноваження основного кола його суб'єктів;

- відсутність чітких цілей та стратегій розвитку людських ресурсів у ключових сферах, секторах чи галузях;

- професійне вигорання людських ресурсів, поглиблення диспропорцій у професійно-кваліфікаційній структурі робочої сили та ії невідповідність потребам суспільства;

- невиправдані інвестиції та державні кошти у навчання та низька ефективність їх використання;

- відсутність ефективного механізму державних закупівель для підготовки необхідного персоналу та забезпечення гарантованої роботи після закінчення навчання;

- невідповідність інституційної структури державного управління потребам громадян, бізнесу, внутрішнім та зовнішнім пріоритетам держави, високій вартості державного управління, відсутності контролю та ефективності.

Для виконання вищевказаних завдань розпорядженням Президента України від 1 лютого 2012 р. 45/2012 затвердив стратегію політики щодо статусу на 2012 2020 роки. Стратегія визначає цілі, основні цілі, пріоритети, на які повинна бути зосереджена державна кадрова політика [12]. Метою кадрової політики у державному управлінні є уникнення надмірної політизації призначень, принципів квотування та традиційної лояльності, що призводить до відкритого служіння корпоративним інтересам, послаблює людські ресурси уряду та зменшує корупцію, а отже, і державну службу та трудові установи при владі. Метою державної політики в державному управлінні $\epsilon$ надання державним органам професійних, компетентних, сучасних вимог, виконання службових обов'язків, прийняття управлінських рішень та забезпечення демократичної, правової та соціальної відповідальності за їх результати держава [14].

Побудова державної кадрової системи та кадрової роботи, їх відповідність потребам соціально-економічного розвитку суспільства та сучасним концепціям 
управління людськими ресурсами є важливим завданням держави. Необхідність відновлення та модернізації цих складових розвитку людського потенціалу обумовлена сучасним напрямком досягнення країною високого рівня соціального забезпечення населення, що відповідає його очікуванням щодо соціальнопрофесійної самореалізації в суспільстві, варте того, щоб жити і працювати. Крім того, структура професійної бази в суспільстві, стандарти основних видів економічної діяльності та кваліфікаційні вимоги до професійно-технічної освіти та напрямків та секторів повинні бути узгоджені зі стандартами СС [14].

Реалізація державної кадрової політики повинна мати на меті досягнення:

- у соціальному плані - високого рівня людського розвитку держави, що відповідає очікуванням населення щодо професійної самореалізації, гідного заробітку;

- в економічному аспекті - забезпечення всіх галузей суспільного виробництва кваліфікованими кадрами, підвищення конкурентоспроможності держави, підвищення добробуту населення;

- в інституційному аспекті - вдосконалення нормативної бази 3 метою впровадження новітніх підходів до управління персоналом;

- в організаційному аспекті - розвиток системи управління робочою силою на основі соціального діалогу та партнерства між державою та суб'єктами господарювання.

Основними завданнями державної кадрової політики є:

- розробка механізмів залучення висококваліфікованих фахівців, фінансовоекономічних працівників, університетів університетів;

- відновлення технології відбору персоналу серед працівників, які мають досвід роботи на порівняльних позиціях у сфері діяльності;

- формування резервів персоналу для лідерських посад у сфері державного управління;

- зміцнення вимог до моральних якостей осіб, залучених до визнання корупції, запобігання можливим конфлікту інтересів, покращення порядку відсотків;

- запровадження сучасних технологій управління технологіями для успішного вирішення завдань управлінських завдань у державному секторі економіки;

- відновлення професійного розвитку серед молоді;

- державна підтримка цільових науково-практичних досліджень у секторі людського розвитку;

- підготовка високого управління Державної служби, здатної забезпечити ефективність державного управління та лідерства в адміністративних та економічних реформах [12]. 
У зв’язку з цим існує нагальна потреба змінити парадигму управління в галузі державної кадрової політики, розробити модель стійкої, ефективної кадрової системи, впровадження нових кадрових технологій. Серед проблем, які потрібно негайно вирішити, є такі:

- невідповідність кадрової політики вимогам трансформаційних процесів у країні. Значна частина існуючого персоналу не готова працювати в сучасній ситуації і в майбутньому, головним чином через нездатність аналізувати, розробляти, захищати, виконувати, своєчасно коригувати управлінські рішення, нести повну відповідальність за завдання;

- неповнота законодавчої бази, яка не забезпечує юридичної чинності, врегулювання та захисту кадрових процесів, не відповідає європейським стандартам у сфері людських ресурсів;

- відсутність стратегічного управління для навчання відповідно до потреб компанії, що забезпечує грамотне здійснення прогнозування, планування, постійної оцінки кадрового стану в країні. Повинен бути запроваджений систематичний підхід до управління всіма частинами сектору людських ресурсів, починаючи від профорієнтації молоді, вибору кар'єри, професійного навчання та технологій на робочому місці до робочого місця;

- розвиток кадрових інститутів, неправомірні дії, низька функціональна надійність кадрових структур, відсутність кваліфікації персоналу у відділі кадрів, що призводить до неефективності, непослідовності в управлінні персоналом на всіх рівнях. Така держава перешкоджає активній професіоналізації багатьох різних видів економічної діяльності та самореалізації людей майже у всіх сферах суспільного виробництва. Політика державної бази повинна базуватися на потужній кадровій системі, сучасних кадрових технологіях;

- перерва між поколіннями будівництва кадрів державного управління, певного професійного прибиральника. Управління походить від покоління, сформованого в незалежній державі, демократизованого, сформованого в умовах ринкової економіки та глобальної інтеграції. Для нього характерні належний прагматизм, амбіційне, нестандартне мислення. У той же час молодому поколінню не вистачає досвіду вищих керівників. Необхідно розробити обгрунтовану програму для забезпечення безперервності професійного розвитку кадрової галузі, оптимального поєднання досвідчених та молодих працівників та підготовки кадрів у всіх сферах соціальної діяльності;

- недостатне використання наукових підходів, результатів наукових досліджень при розробці та реалізації державної кадрової політики. Галузь наукових знань дуже динамічна, тому наукове обгрунтування повинно бути постійною та невід'ємною частиною управління, особливо у сфері кадрової політики [4]. 
Серед проблем формування кадрової політики - відсутність чітких уявлень про пріоритети соціально-економічного розвитку держави та затягування низки соціально-політичних реформ у різних сферах життя. (Адміністративнотериторіальна, судова, економічна реформи тощо) через відсутність системи законодавчого забезпечення цих реформ [4].

Отже, проблеми були пов'язані 3: - відсутність юридично визнаного відповідального координатора реформного комплексу, що призвело до місцевих урядових програм з низьким рівнем ефективності та закладеності державного бюджету з вторинними завданнями;

- порушення освіти, регулювання яких є частиною національної безпеки i повинна виникнути від національних пріоритетів та ринкових оцінок ринку праці;

- відсутність моніторингу потреб фахівців з відповідним рівнем підготовки кваліфікацій у всіх галузях економіки та національності держави;

- недостатній юридичний та соціальний захист працівників, таких як державних, так i приватних секторів, політичних та економічних впливів державних установ, процесів, викликаних глобальною економічною кризою, що створює ризик розвитку безробіття;

- недостатня увага роботодавців щодо своєчасного відновлення професіоналізму працівника, що викликає некомпетентну потребу у товарах та послугах.

Кадрова політика держави повинна враховувати специфіку ключових об’єктів, таких як кадровий потенціал різних галузей суспільного виробництва: промисловості, агропромислового комплексу та соціально-гуманітарної сфери.

Процес створення та реалізації кадрової політики держави у кожному із цих секторів складається 3 таких універсальних етапів: - визначення потреб у персоналі даної дирекції (з урахуванням стану системи освіти, охорони здоров’я та демографічних процесів);

- розробка стратегії розвитку людських ресурсів для цього сектору;

- оперативне управління задоволенням потреб сектору в кадрах;

- використання персоналу (працевлаштування, організація праці, підвищення кваліфікації шляхом навчання, перепідготовки, підвищення кваліфікації, стабілізація персоналу через політику заробітної плати, соціальних служб та соціальних виплат тощо);

- контроль, моніторинг та оцінка кадрової ситуації на всіх етапах розробки та реалізації державної кадрової політики [7].

Потрібно суттєво вдосконалити кадровий склад державної адміністрації та місцевого самоврядування через низку факторів, головним чином: Недосконалість нормативної бази щодо персоналу у сфері державного управління; 
- нестабільність персоналу, недоліки у підборі, використанні та утриманні контролюючого персоналу та порушення принципу безперервності роботи;

- відсутність прозорості діяльності органів державної влади та місцевих громад у сфері кадрів;

- низка проблем, успадкованих від попередньої влади, головним чином корупція, погана мораль, невиконання вимог політичного нейтралітету;

- недостатній рівень професіоналізму та адміністративної культури представників та агентів місцевого самоврядування, недосконалість їхньої системи підготовки та недостатні ресурси для цього процесу;

- низький престиж державної служби, служби в місцевих громадах, низький рівень соціальної мотивації та соціального захисту державних службовців та місцевих державних службовців;

- відсутність інтегрованої системи управління персоналом та недостатній розвиток закладів для професіоналізації системи державного управління, особливо підготовки та використання кадрового резерву;

- недосконалість громадського та державного контролю за діяльністю державного управління, персоналом місцевої громади, критеріями та механізмами об’єктивної оцінки їх роботи [15].

Сьогодні пріоритетом $\epsilon$ сучасна науково обгрунтована політика щодо управління персоналом в уряді та адміністрації, а іiі основними напрямами повинні бути: чітке визначення цілей та завдань, принципів функціонування державної служби та державної влади, забезпечення їх ефективної роботи. Держава, як головний суб'єкт кадрової політики та головний роботодавець кваліфікованих управлінських кадрів, покликана вдосконалити існуючі механізми створення, розподілу та раціонального використання людських ресурсів, що $\epsilon$ предметом кадрової політики на різних рівнях суспільства: центральний, регіональний, галузевий та місцевий.

Висновки. Перспективними напрямками кадрового забезпечення в сфері державного управління при реалізації сучасної кадрової політики повинні бути: стабілізація соціальної бази кадрової політики; чітке правове розмежування рамок i лімітів кадрового впливу суб'єктів державної кадрової політики; гармонізація i поєднання особистих, групових, суспільних, державних інтересів у кадровій сфері; офіційне визнання персоналу органів державного управління головним об'єктом кадрової політики; підвищення ролі кожного державного органу, місцевого самоврядування, громадянина в розробці і реалізації кадрової політики; розробка механізмів правового регулювання кадрових процесів і відносин.

Механізм реалізації сучасної кадрової політики в сфері державного управління передбачає такі рівні змісту: концептуальний, результатом якого має стати розробка теоретичних основ сучасної кадрової політики; нормативно- 
правова, яка передбачає підготовку відповідної нормативно-правової бази; організаційна, яка визначає спеціальні установи і органи, уповноважені проводити кадрову політику; технологічний, що включає в себе конкретні ефективні форми, методи, методи роботи з персоналом в державному управлінні.

Таким чином, відповідно до основними цілями, поставленими Стратегією державної кадрової політики - реалізація державної кадрової політики в сфері державного управління в першу чергу вимагає модернізації системи підготовки кадрів в галузі науки «Державне управління», акцентував увагу на пріоритетах національної стратегії людського розвитку України.

\section{Лimepamypa:}

1. Вольська О. М., Сапельнікова Н. Л., Кольцова Д. В. Актуальні проблеми кадрового забезпечення органів публічної влади. Вісник Національної академії Державної прикордонної служби України. Серія: Державне управління. - 2019. - Вип. 1. - С. 32-40.

2. Гогіна Л. Нормативно-правове забезпечення розмежування професійного навчання кадрів різних управлінських рівнів / Л. Гогіна, Ю. Іванченко // Вісник НАДУ. - 2004. - № 3. C. $157-163$.

3. Гогіна Л. Проблемні питання професійної підготовки керівних кадрів державної служби та служби в органах місцевого самоврядування / Л. Гогіна, Ю. Іванченко // Вісник Української академії державного управління. - 2003. - № 2. - С. 297-307.

4. Губа О. Концептуально-методологічні підходи до дослідження проблем формування і реалізації кадрової політики / О. Губа // Вісник УАДУ. - 2003. - № 2. - С. 284-293.

5. Дембіцька С. Підготовка кадрів органів державного управління у сфері надання послуг населенню України / С. Дембіцька // Науковий вісник. - Львів: ЛьвДУВС, 2018. - № 3. C. $170-176$.

6. Дубенко С. Державна служба і державні службовці в Україні: навч.-метод. посіб. / С. Дубенко - К.: Ін Юре, 2014. - 244 с

7. Державна кадрова політика в Україні: стан, проблеми та перспективи розвитку: наук. доп. / Авт. кол.: Ю.В. Ковбасюк, К.О. Ващенко, Ю.П. Сурмін та ін. - К.: НАДУ, 2012. - 72 с.

8. Жовнірчик Я.Ф. Сутність формування кар'єри державного службовця в організації його діяльності / Я.Ф. Жовнірчик // Наук. вісник Академії муніципал. управління: Серія "Управління". Вип. 3 (2013 ). - Держ. упр. та місц. самовр. - Заг. ред. В.П. Присяжнюка, В.Д. Бакуменка. - К.: ВПЦ АМУ, 2013. - С. $50-59$.

9. Ковальова О. М. Сутність кадрового потенціалу та напрями підвищення ефективності його використання. URL: http://pev.kpu.zp.ua/ journals/2018/5_10_uk/39.pdf.

10. Куйбіда В. С., Петров О. М., Федулова Л. І., Андрощук Г. О. Цифрові компетенції як умова формування якості людського капіталу : аналіт. зап. Київ / НАДУ, 2019. 28 с. URL: http://academy.gov.ua/pages/dop/198/files/90a7d5c8- d10a-4f8f-8987-4d1077fdc8f6.pdf.

10 Михненко А. М. Особливості моделювання системи пошуку та відбору кадрів в органах виконавчої влади України / А. Михненко, Т. Лєкарь. - [Електронний ресурс]. - Режим доступу: http.www.nbuv.gov.ua.e.journals.

12. Наказ Президента України "Про Стратегію державної кадрової політики на 2012 — 2020 роки" від 01.02.2012 p. № 45/2012 [Електронний ресурс]. — Режим доступу: http://zakon4.rada.gov.ua/laws/show/45/2012. 
13. Проблеми розвитку публічного управління в Україні : пленар. засід. наук.-практ. конф. за міжнар. уч. до 100-річчя запровадження державної служби України (13 квітня 2018 р., м. Львів) / за наук. ред.чл.-кор. НАН України С. Загорського. Львів: ЛРІДУ НАДУ, 2018. 124 с.

14. Про Стратегію державної кадрової політики на 2012-2020 роки [Електронний ресурс] - Режим доступу: https://zakon.rada.gov.ua/laws/show/45/2012\#Text.

15. Шляхи реалізації стратегії державної кадрової політики на 2012-2020 роки в державній пенітенціарній службі України [Електронний ресурс]. - Режим доступу: https://minjust.gov.ua/m/str_43473.

\section{References:}

1. Volska, O.M., Sapelnikova, N.L., Koltsova, D.V. (2019). Aktualni problemy kadrovoho zabezpechennia orhaniv publichnoi vlady [Actual problems of staffing public authorities]. Visnyk Natsionalnoi akademii Derzhavnoi prykordonnoi sluzhby Ukrainy. Seriia: Derzhavne upravlinnia Bulletin of the National Academy of the State Border Guard Service of Ukraine. Series: Public Administration, 1, 32-40 [in Ukrainian].

2. Hohina, L., Ivanchenko, Yu. (2004). Normatyvno-pravove zabezpechennia rozmezhuvannia profesiinoho navchannia kadriv riznykh upravlinskykh rivniv [Normative-legal provision of delimitation of professional training of personnel of different management levels]. Visnyk NADU Visnyk of NAPA, 3, 157-163 [in Ukrainian].

3. Hohina, L., Ivanchenko, Yu. (2003). Problemni pytannia profesiinoi pidhotovky kerivnykh kadriv derzhavnoi sluzhby ta sluzhby $\mathrm{v}$ orhanakh mistsevoho samovriaduvannia [Problematic issues of professional training of managers of the civil service and service in local government]. Visnyk Ukrainskoi akademii derzhavnoho upravlinnia - Bulletin of the Ukrainian Academy of Public Administration, 2, 297-307 [in Ukrainian].

4. Huba, O. (2003). Kontseptualno-metodolohichni pidkhody do doslidzhennia problem formuvannia i realizatsii kadrovoi polityky [Conceptual and methodological approaches to the study of problems of formation and implementation of personnel policy]. Visnyk NADU - Visnyk of NAPA, 2, 284-293 [in Ukrainian].

5. Dembitska, S. (2018). Pidhotovka kadriv orhaniv derzhavnoho upravlinnia u sferi nadannia posluh naselenniu Ukrainy [Training of public administration in the field of providing services to the population of Ukraine]. Naukovyi visnyk - Scientific Bulletin, 3, 170-176 [in Ukrainian].

6. Dubenko, S. (2014). Derzhavna sluzhba i derzhavni sluzhbovtsi v Ukraini [Civil service and civil servants in Ukraine]. Kyiv: In Yure [in Ukrainian].

7. Kovbasiuk, Yu.V., Vashchenko, K.O., Surmin, Yu.P., et al. (2012). Derzhavna kadrova polityka v Ukraini: stan, problemy ta perspektyvy rozvytku [State personnel policy in Ukraine: status, problems and prospects]. Kyiv: NADU [in Ukrainian].

8. Zhovnirchyk, Ya.F. (2013). Sutnist formuvannia kariery derzhavnoho sluzhbovtsia v orhanizatsii yoho diialnosti [The essence of career formation of a civil servant in the organization of his activity]. Nauk. visnyk Akademii munitsypal. upravlinnia: Seriia "Upravlinnia" - Scientific Bulletin of the Municipal Academy of management: "Management" series, 3, 50-59 [in Ukrainian].

9. Kovalova, O.M. Sutnist kadrovoho potentsialu ta napriamy pidvyshchennia efektyvnosti yoho vykorystannia [The essence of human resources and ways to improve the efficiency of its use]. Pryazovskyi ekonomichnyi visnyk - Pryazovskyi economic herald, 5(10), 218-222. Retrieved from http://pev.kpu.zp.ua/journals/2018/5_10_uk/39.pdf [in Ukrainian].

10. Kuibida, V. S., Petrov, O. M., Fedulova, L. I., Androshchuk, H.O. (2019). Tsyfrovi 
kompetentsii yak umova formuvannia yakosti liudskoho kapitalu [Digital competencies as a condition for the formation of the quality of human capital]. Kyiv: NADU. Retrieved from http://academy.gov.ua/pages/dop/198/files/90a7d5c8-d10a-4f8f-8987-4d1077fdc8f6.pdf [in Ukrainian].

11 Mykhnenko, A.M., Liekar, T. (n.d.). Osoblyvosti modeliuvannia systemy poshuku ta vidboru kadriv v orhanakh vykonavchoi vlady Ukrainy [Features of modeling the system of search and selection of personnel in the executive authorities of Ukraine]. academy.gov.ua. Retrieved from http://academy.gov.ua/ej/ej5/txts/07mamvvu.htm [in Ukrainian].

12. Nakaz Prezydenta Ukrainy "Pro Stratehiiu derzhavnoi kadrovoi polityky na 2012-2020 roky" : vid 01.02.2012 r., № 45/2012 [Order of the President of Ukraine "On the Strategy of State Personnel Policy for 2012-2020" dated 01.02.2012 № 45/2012]. zakon.rada.gov.ua. Retrieved from http://zakon4.rada.gov.ua/laws/show/45/2012 [in Ukrainian].

13. Zahorskyi, S. (2018). Problemy rozvytku publichnoho upravlinnia v Ukraini - Problems of development of public administration in Ukraine : plenary session of the scientific-practical conference with international participation to the 100th anniversary of the introduction of the civil service of Ukraine. Lviv: LRIDU NADU [in Ukrainian].

14. Pro Stratehiiu derzhavnoi kadrovoi polityky na 2012-2020 roky [On the Strategy of the state personnel policy for 2012-2020]. zakon.rada.gov.ua. Retrieved from https://zakon.rada.gov.ua/laws/ show/45/2012\#Text [in Ukrainian].

15. Zinchenko, S.A. (n.d.). Shliakhy realizatsii stratehii derzhavnoi kadrovoi polityky na 20122020 roky v derzhavnii penitentsiarnii sluzhbi Ukrainy [Ways to implement the strategy of state personnel policy for 2012-2020 in the state penitentiary service of Ukraine]. minjust.gov.ua. Retrieved from https://minjust.gov.ua/m/str_43473 [in Ukrainian]. 